\title{
The Different Activation of int Genes in Mammary Carcinomas Developed in Three Mouse Strains Harboring Mouse Mammary Tumor Viruses Derived from DD/Tbr
}

\author{
Masaaki OKUMOTO, Ryosuke NISHIKAWA, Mineko IWAI, Yoshiaki IWAI, \\ Shunsuke IMAI*, Nobuko Mori, Yasuhiko TAKAMORI**, \\ and Osamu YAGASAKI***
}

\author{
Department of Applied Bioscience, Research Institute for Advanced Science and Technology, \\ University of Osaka Prefecture, 174-16 Shinke-cho, Sakai-shi, Osaka 593, *Department of \\ Pathology, Nara Medical University, 840 Shijo-cho, Kashiwara-shi, Nara 634, \\ ** Department of Veterinary Radiology, University of Osaka Prefecture, \\ 4-804 Mozuume-machi, Sakai-shi, Osaka 593, and ${ }^{* * *}$ Department of \\ Veterinary Phamacology, University of Osaka Prefecture, \\ 4-804 Mozuume-machi, Sakai-shi, Osaka 593, Japan
}

(Received 29 March 1991/Accepted 8 May 1991)

\begin{abstract}
RNA expressions of common integration site (int) genes and several cnogenes were investigated in mammary carcinomas spontaneously developed in different three strains of mice; DD/Tbr, NIH Swiss and BALB/c which harbor DD-MMTV derived from $\mathrm{DD} / \mathrm{Tbr}$ mouse. Latter two strains of mice were designated $\mathrm{NIH} / \mathrm{Mtv}^{+}$ and $\mathrm{BALB} / \mathrm{Mtv}^{+}$, respectively. An increased expession of int -1 (wnt-1) and int-2 genes was observed in 56\% (9/16) and 50\% (8/16) of mammary carcinomas of DD/ Tbr mice, respectively. Either int-1 or int-2 RNAs were expressed in 81\% (13/16) of the carcinomas of $\mathrm{DD} / \mathrm{Tbr}$ mice. IN NIH/Mtv mice, activation of int-1 and int-2 was observed in $41 \%(7 / 17)$ and $24 \%$ (4/17) of mammary carcinomas, respectively. Either int-1 or int-2 RNAs were expressed in $47 \%(8 / 17)$ of the carcinomas examined in this strain. In BALB/ $\mathrm{Mtv}^{+}$mice, on the other hand, either int-1 or int-2 genes were transcribed into RNAs at low frequency (33\%:3/9). These results suggest that the frequency of activation of int genes in mammary carcinomas induced by the same DD-MMTV in three strains of mice is genetically defined characteristics of these strains, and that the involvement of int-1 and int-2 genes in virus-induced mammary carcinogenesis may be influenced by genetic properties of animals. The activation of int-1 and int-2 genes did not clearly correlate with an increase in the expression of oncogenes examined; $\mathrm{H}-r a s, \mathrm{~K}-r a s, \mathrm{~N}-r a s, m y c, r a f, f g r, f m s$, erbB, mos, and src genes. - KEY WORDS : int gene, mammary carcinoma, mouse mammary tumor virus, oncogene, RNA expression
\end{abstract}

Mammary carcinomas (MC) induced by mouse mammary tumor viruses (MMTV) acquire various numbers of newly integrated MMTV proviruses in addition to edogenous MMTV [10]. Some of these additional MMTV proviruses are integrated at common sites in cellular DNA of MC. The cellular DNA sequences of the common sites are molecularly cloned and designated as int-1 [11] (later, wnt1), int $-2[2,15]$ and int -3 [5]. The int -1 gene products are glycoproteins and seem to be some growth and differentiation factors [1, 14]. Trascriptional activation of int-1 gene is an initiating event in multistep carcinogenesis [21]. Amino acid sequence of the int-2 protein have homology to fibroblast growth factor [3, $4,9]$. The int -2 gene plays multiple roles in the embryo stages of development [22]. Such int genes are considered to play an important role in viral mammary tumorigenesis [12]. The frequency of activation of these genes, however, varies greatly among mouse strains 
$[7,12]$. These facts raise the question which of MMTV and host cells determine the extent of contribution of int genes in viral mammary tumorigenesis.

We have previously examined DNA rearrangements of int -1 and int -2 regions of MCs developed in DD/Tbr, and in the progeny of $\mathrm{NIH}$ Swiss $\left(\mathrm{NIH} / \mathrm{Mtv}^{+}\right)$and $\mathrm{BALB} / \mathrm{c}$ mice $\left(\mathrm{BALB} / \mathrm{Mtv}^{+}\right)$, whch were infected with MMTV (DD-MMTV) derived from DD/Tbr mice. In 18 MCs of $\mathrm{DD} / \mathrm{Tbr}$ mice examined, the rearrangements of int -1 and int -2 regions were observed in $10 \mathrm{MCs}(56 \%)$ and $2 \mathrm{MCs}(11 \%)$, respectively In contrast, the rearrangements of int -1 and/or int -2 regions were in only one (11\%) out of 9 MCs in $\mathrm{NIH} / \mathrm{Mtv}^{+}$mice and only one (13\%) out of $8 \mathrm{MCs}$ in $\mathrm{BALB} / \mathrm{Mtv}^{+}$mice, respectively [unpublished data].

In the present study, the level of RNA expression of int genes were examined in MCs the three strains of mice, which were persitently infected with the DD-MMTV. Increased expressions of either int -1 or int-2 genes were $81 \%$ in $\mathrm{DD} / \mathrm{Tbr}, 47 \%$ in $\mathrm{NIH} / \mathrm{Mtv}^{+}$and $33 \% \mathrm{BALB} /$ $\mathrm{Mtv}^{+}$mice. This suggests that the frequency of expression of int genes in mammary carcinomas depends largely on genetic background of hosts.

\section{Materials and Methods}

Mice : The origin of DD/Tbr mice was described previously [6]. Newborns of NIH Swiss and $\mathrm{BALB} / \mathrm{c}$ mice were intraperitoneally injected with DD-MMTV produced by a mammary tumor cell line within 48 hours after birth [8]. These NIH Swiss and BALB/c mice were designated $\mathrm{NIH} / \mathrm{Mtv}^{+}$and $\mathrm{BALB} / \mathrm{Mtv}^{+}$, respectively. While about a half of $\mathrm{BALB} / \mathrm{Mtv}^{+}$ females develop MC by 20 months old, all NIH/ $\mathrm{Mtv}^{+}$females develop $\mathrm{MC}$ within 1 year after birth.

All animals were kept in air-conditioned rooms where the temperature was $24 \pm 0.5^{\circ} \mathrm{C}$, the relative humidity $55 \pm 5 \%$, and automatic lighting during $7: 00 \mathrm{a} . \mathrm{m} .-7: 00$ p. m.. The mice were given a commercial diet $(\mathrm{MF}$, Oriental Yeast, Co.) and water ad libitum.

RNA extraction : RNA was extracted by the method as described previously [13].

Hybridization procedure : Hybridization probes included the following DNA fragments : MMTV LTR [11], MMTVgag-pol [2], MMTVenv, int
$1 \mathrm{c}[11]$, int-2 $\mathrm{c}$ and int-2e [2], int -3 [5], $\mathrm{K}-$ ras, $\mathrm{H}-r a s, \mathrm{~N}-r a s, \mathrm{c}-m y c, \mathrm{v}-r a f, \mathrm{v}-f g r, \mathrm{v}-f m s$, $\mathrm{v}$-erbB, v-mos, v-src and actin. Latter 8 oncogene DNAs were gifts from Japanese Cancer Research Resources Bank (JCRB)-Gene. All probes were labelled with ${ }^{32} \mathrm{P}$-dCTP $(3,000 \mathrm{Ci} /$ mmol, Amersham) by nick translation at specific activities higher than $10^{8} \mathrm{cpm} / \mu \mathrm{g}$ [18]. Dot-blotted RNAs on the nitrocellulose filters were hybridized with ${ }^{32} \mathrm{P}$-labelled DNA probes at $42^{\circ} \mathrm{C}$ for $18 \mathrm{hr}$ or more, as described by Thomas [20]. X-ray films were exposed to the filters in $-80^{\circ} \mathrm{C}$. Relative quantities of hybridizable RNA to DNA probes were determined by a densitometer type P-2 (Fuji Film Co.). Optical densities of spots hybridized with ${ }^{32} \mathrm{P}$-labelled actin were used as standard.

\section{Results}

Expression of MMTV proviral genomes : RNA expressions of MMTV in MCs from DD/Tbr, $\mathrm{NIH} / \mathrm{Mtv}^{+}$and BALB/ $/ \mathrm{Mtv}^{+}$mice were determined by the dot blot hybridization analysis using DNA probes of MMTVgag-pol and MMTVenv. The expression level of RNAs hybridizable to the MMTVgag-pol (Fig. 1A, 1B) and MMTVenv (data not shown) in all tumors from $\mathrm{DD} / \mathrm{Tbr}, \mathrm{NIH} / \mathrm{Mtv}^{+}$and $\mathrm{BALB} / \mathrm{Mtv}^{+}$mice examined were remarkably increased in comparison with those in livers from the tumor-bearing mice. All the tumors contain one or more newly acquired MMTV proviruses in addition to endogenous MMTV proviruses [unpublished data]. Increased level of MMTV transcripts may be due to newly acquired MMTV proviruses.

Activation of int -1 , int -2 , and int -3 genes : The expression of int -1 gene was examined in MCs from DD/Tbr, NIH/Mtv ${ }^{+}$and BALB/ $\mathrm{Mtv}^{+}$mice (Fig. 2A, 2B and Table 1). Elevated expression of the int-1 gene was observed in 9 of $16 \mathrm{MCs}(56 \%)$ from DD/Tbr, 7 of 17 MCs (41\%) from NIH/ $\mathrm{Mtv}^{+}$, and 2 of $9 \mathrm{MCs}$ (22\%) from BALB/ $\mathrm{Mtv}^{+}$mice. Frequency of elevated transcription of int -1 gene in $\mathrm{MC}$ of $\mathrm{DD} / \mathrm{Tbr}$ was significantly higher than that in $\mathrm{MC}$ of $\mathrm{BALB} / \mathrm{Mtv}^{+}$. The high level of RNA expression of int-1 was observed in some MCs ; E 50 and C 58 of DD/Tbr and M 35 and $\mathrm{M} 38$ of $\mathrm{NIH} / \mathrm{Mtv}^{+}$. The medium level of expression was detected in MCs of DD/Tbr (M 36, B 23, B 25 and C 61), NIH/ $\mathrm{Mtv}^{+}$(MT 1) 
A

$\begin{array}{lllllllllllllllll}1 & 2 & 3 & 4 & 5 & 6 & 7 & 8 & 9 & 10 & 11 & 12 & 13 & 14 & 15 & 16 & 17\end{array}$ Liv E47 E49 E50 B13 M36 A15 A16 B23 B24 B25 B14 $\quad$ C58 C59 C62

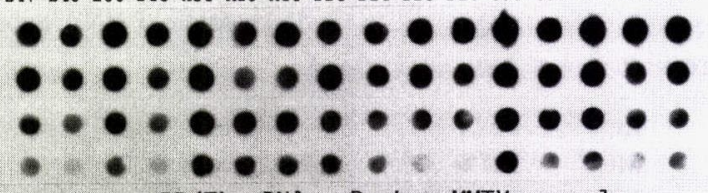

DD/Tbr RNA Probe: MMTVgag-pol

B

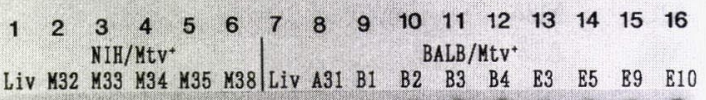

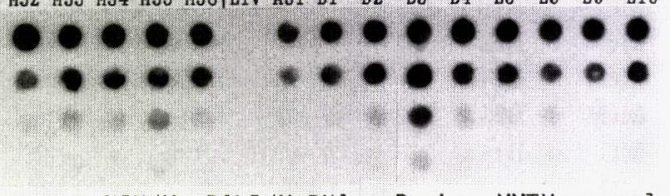

NIH/M, BALB/M RNA Probe: MMTVgag-pol

Fig. 1. Expression of MMTV proviruses in MCs from DD/Tbr (A), $\mathrm{NIH} / \mathrm{Mtv}^{+}$and BALB/ $\mathrm{Mtv}^{+}$mice (B). Three-fold serially diluted RNA was transferred to nitrocellose filters at the density of 0.11 , $0.33,1.0$, and $3 \mu \mathrm{g}$ per each spot from the top to the bottom on the same column, respectively. Dot-blotted RNA on the filters were hybridized with ${ }^{32} \mathrm{P}$-labelled MMTVgag-pol probe DNA. (A) column 1 : liver; columns 2 to 17 : MC. (B) column $1:$ liver of NIH $/ \mathrm{Mtv}^{+}$; columns 2 to $6: \mathrm{MCs}$ of $\mathrm{NIH} / \mathrm{Mtv}^{+}$; column $7:$ liver of $\mathrm{BALB} / \mathrm{Mtv}^{+}$; columns 8 to $16: \mathrm{MCs}$ of $\mathrm{BALB} / \mathrm{Mtv}^{+}$.

A

$\begin{array}{lllllllllllllllll}1 & 2 & 3 & 4 & 5 & 6 & 7 & 8 & 9 & 10 & 11 & 12 & 13 & 14 & 15 & 16 & 17\end{array}$

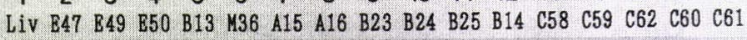

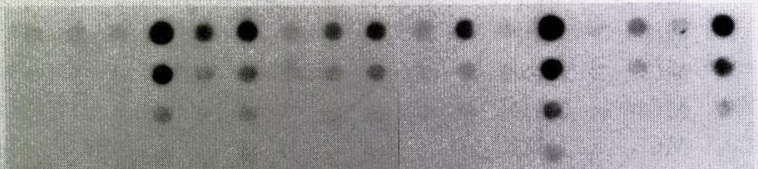

DD/Tbr RNA Probe: int-lc

B

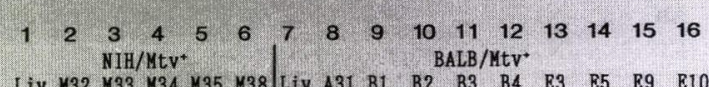

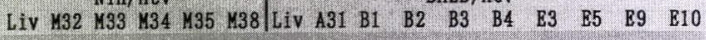

○

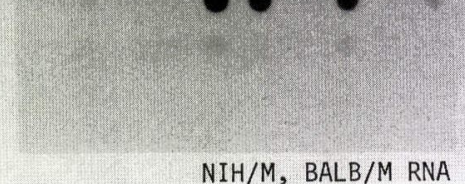

Probe: int-1c

Fig. 2. Activation of a putative mammary oncogene, int -1 , in $\mathrm{MCs}$ from DD/Tbr (A), NIH/Mtv ${ }^{+}$and BALB/Mtv ${ }^{+}$mice (B). Procedures is the same to the legend to Figure 1 except with int $-1 \mathrm{c}$ probe. (A) column 1 : liver ; columns 2 to 17 : MC. (B) column 1 : liver of $\mathrm{NIH} / \mathrm{Mtv}^{+}$; columns 2 to $6: \mathrm{MCs}$ of $\mathrm{NIH} / \mathrm{Mtv}^{+}$; column 7 : liver of $\mathrm{BALB} / \mathrm{Mtv}^{+}$; columns 8 to $16: \mathrm{MCs}$ of $\mathrm{BALB} / \mathrm{Mtv}^{+}$. 
Table 1. Expression of RNA in mammary carcinomas and livers of $\mathrm{DD} / \mathrm{Tbr}, \mathrm{NIH} / \mathrm{Mtv}^{+}$and $\mathrm{BALB} / \mathrm{Mtv}^{+}$mice

\begin{tabular}{|c|c|c|c|c|c|c|c|}
\hline \multirow{2}{*}{\multicolumn{2}{|c|}{$\begin{array}{c}\text { RNA } \\
\text { sources }\end{array}$}} & \multirow{3}{*}{$\begin{array}{c}\begin{array}{c}\text { RNA } \\
\text { no. }\end{array} \\
\text { DL1 }\end{array}$} & \multicolumn{5}{|c|}{ Expression of RNA hybridizable to ${ }^{11}$} \\
\hline & & & \multirow{2}{*}{$\frac{\text { int }-1}{-}$} & \multirow{2}{*}{$\frac{i n t-2}{-}$} & \multirow{2}{*}{$\frac{i n t-3}{-}$} & \multirow{2}{*}{$\frac{\mathrm{H} \text {-ras }}{+}$} & \multirow{2}{*}{$\frac{\text { K-ras }}{+}$} \\
\hline $\mathrm{DD} / \mathrm{Tbr}$ & $\mathrm{Lv}^{2)}$ & & & & & & \\
\hline $\mathrm{DD} / \mathrm{Tbr}$ & $\mathrm{MC}^{2)}$ & $\mathrm{E} 47$ & - & - & - & + & +++ \\
\hline $\mathrm{DD} / \mathrm{Tbr}$ & $\mathrm{MC}$ & E49 & - & - & - & ++ & ++ \\
\hline $\mathrm{DD} / \mathrm{Tbr}$ & $\mathrm{MC}$ & $\mathrm{E} 50$ & ++ & - & - & + & ++ \\
\hline $\mathrm{DD} / \mathrm{Tbr}$ & $\mathrm{MC}$ & B13 & + & - & - & +++ & ND \\
\hline $\mathrm{DD} / \mathrm{Tbr}$ & $\mathrm{MC}$ & M36 & ++ & ++ & - & ++ & ++ \\
\hline $\mathrm{DD} / \mathrm{Tbr}$ & $\mathrm{MC}$ & A15 & - & - & - & ++ & +++ \\
\hline $\mathrm{DD} / \mathrm{Tbr}$ & $\mathrm{MC}$ & A 16 & + & - & - & +++ & ++ \\
\hline $\mathrm{DD} / \mathrm{Tbr}$ & $\mathrm{MC}$ & $\mathrm{B} 23$ & ++ & + & - & + & ++ \\
\hline $\mathrm{DD} / \mathrm{Tbr}$ & $\mathrm{MC}$ & B24 & - & ++++ & + & ++ & + \\
\hline $\mathrm{DD} / \mathrm{Tbr}$ & $\mathrm{MC}$ & B25 & ++ & ++ & - & + & ++ \\
\hline $\mathrm{DD} / \mathrm{Tbr}$ & $\mathrm{MC}$ & B14 & - & +++ & - & ++ & + \\
\hline $\mathrm{DD} / \mathrm{Tbr}$ & $\mathrm{MC}$ & C58 & ++++ & - & - & +++ & ++ \\
\hline $\mathrm{DD} / \mathrm{Tbr}$ & $\mathrm{MC}$ & C59 & - & + & - & +++ & ND \\
\hline $\mathrm{DD} / \mathrm{Tbr}$ & $\mathrm{MC}$ & C62 & + & - & - & +++ & ++ \\
\hline $\mathrm{DD} / \mathrm{Tbr}$ & $\mathrm{MC}$ & $\mathrm{C} 60$ & - & ++++ & - & ++ & ++ \\
\hline $\mathrm{DD} / \mathrm{Tbr}$ & $\mathrm{MC}$ & $\mathrm{C} 61$ & ++ & + & - & ++ & +++ \\
\hline $\mathrm{NIH} / \mathrm{Mtv}^{+}$ & $\mathrm{Lv}$ & NL1 & - & - & - & - & - \\
\hline $\mathrm{NIH} / \mathrm{Mtv}^{+}$ & $\mathrm{MC}$ & M32 & - & - & - & ++ & ++ \\
\hline $\mathrm{NIH} / \mathrm{Mtv}^{+}$ & $\mathrm{MC}$ & M33 & - & - & - & ++ & + \\
\hline $\mathrm{NIH} / \mathrm{Mtv}^{+}$ & $\mathrm{MC}$ & M34 & - & - & - & ++ & + \\
\hline $\mathrm{NIH} / \mathrm{Mtv}^{+}$ & $\mathrm{MC}$ & M35 & +++ & ++ & - & + & + \\
\hline $\mathrm{NIH} / \mathrm{Mtv}^{+}$ & $\mathrm{MC}$ & M38 & +++ & - & - & + & ++ \\
\hline $\mathrm{NIH} / \mathrm{Mtv}^{+}$ & $\mathrm{MC}$ & MT1 & ++ & - & - & + & + \\
\hline $\mathrm{NIH} / \mathrm{Mtv}^{+}$ & $\mathrm{MC}$ & MT2 & + & + & - & + & - \\
\hline $\mathrm{NIH} / \mathrm{Mtv}^{+}$ & $\mathrm{MC}$ & $\mathrm{N} 7 \mathrm{R}$ & + & + & - & + & - \\
\hline $\mathrm{NIH} / \mathrm{Mtv}^{+}$ & $\mathrm{MC}$ & N8R & - & - & - & + & - \\
\hline $\mathrm{NIH} / \mathrm{Mtv}^{+}$ & $\mathrm{MC}$ & N9R & - & ++ & - & ++ & + \\
\hline $\mathrm{NIH} / \mathrm{Mtv}^{+}$ & $\mathrm{MC}$ & N10R & - & - & - & + & + \\
\hline $\mathrm{NIH} / \mathrm{Mtv}^{+}$ & $\mathrm{MC}$ & N11R & - & - & - & + & + \\
\hline $\mathrm{NIH} / \mathrm{Mtv}^{+}$ & $\mathrm{MC}$ & $\mathrm{N} 12 \mathrm{R}$ & - & - & - & - & + \\
\hline $\mathrm{NIH} / \mathrm{Mtv}^{+}$ & $\mathrm{MC}$ & N13R & + & - & - & - & + \\
\hline $\mathrm{NIH} / \mathrm{Mtv}^{+}$ & $\mathrm{MC}$ & N15R & - & - & - & - & ++ \\
\hline $\mathrm{NIH} / \mathrm{Mtv}^{+}$ & $\mathrm{MC}$ & N16R & + & - & - & + & + \\
\hline $\mathrm{NIH} / \mathrm{Mtv}^{+}$ & $\mathrm{MC}$ & N17R & - & - & - & + & ++ \\
\hline $\mathrm{NIH} / \mathrm{Mtv}^{+}$ & Lv & N18R & - & - & - & + & + \\
\hline $\mathrm{BALB} / \mathrm{Mtv}^{+}$ & $\mathrm{Lv}$ & BL1 & - & - & ND & - & + \\
\hline $\mathrm{BALB} / \mathrm{Mtv}^{+}$ & $\mathrm{MC}$ & A31 & ++ & - & ND & - & + \\
\hline $\mathrm{BALB} / \mathrm{Mtv}^{+}$ & $\mathrm{MC}$ & $\mathrm{B} 1$ & - & ++ & ND & + & + \\
\hline $\mathrm{BALB} / \mathrm{Mtv}^{+}$ & $\mathrm{MC}$ & $\mathrm{B} 2$ & - & - & ND & ++ & + \\
\hline $\mathrm{BALB} / \mathrm{Mtv}^{+}$ & $\mathrm{MC}$ & B3 & - & - & ND & - & ++ \\
\hline $\mathrm{BALB} / \mathrm{Mtv}^{+}$ & $\mathrm{MC}$ & B4 & - & - & ND & + & + \\
\hline $\mathrm{BALB} / \mathrm{Mtv}^{+}$ & $\mathrm{MC}$ & E3 & + & - & ND & - & ++ \\
\hline $\mathrm{BALB} / \mathrm{Mtv}^{+}$ & $\mathrm{MC}$ & E5 & - & - & ND & + & +++ \\
\hline $\mathrm{BALB} / \mathrm{Mtv}^{+}$ & $\mathrm{MC}$ & E9 & - & - & ND & - & ++ \\
\hline $\mathrm{BALB} / \mathrm{Mtv}^{+}$ & $\mathrm{MC}$ & E10 & - & - & ND & + & ++ \\
\hline
\end{tabular}

RNA extraction and hybridization procedure are described in Materials and Methods. 1) Rerative quantities of hybridizable RNA to DNA probes were determined by a densitometer. ND : not determined. 2) Lv : liver, MC : mammary carcinoma. 


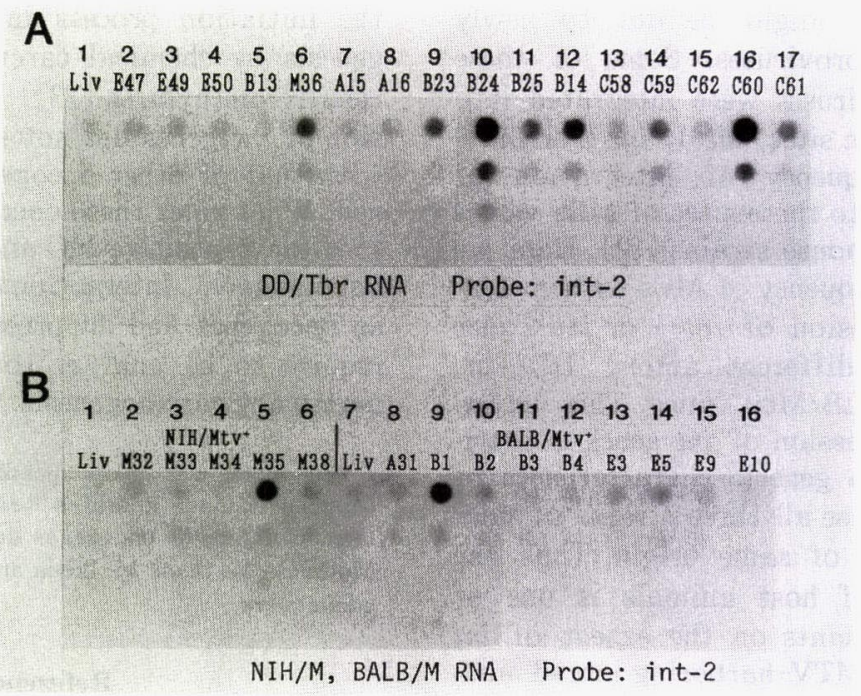

Fig. 3. Activation of another putative mammary oncogene, int -2 , in MCs from DD/Tbr (A), NIH/Mtv and $\mathrm{BALB} / \mathrm{Mtv}^{+}$mice (B). Procedures is the same to the legend to Figure 1. (A) column 1 : liver; columns 2 to $17: \mathrm{MC}$. (B) column 1 : liver of $\mathrm{NIH} / \mathrm{Mtv}^{+}$; columns 2 to $6: \mathrm{MCs}$ of $\mathrm{NIH} / \mathrm{Mtv}^{+}$; column $7:$ liver of BALB/ $\mathrm{Mtv}^{+}$; columns $8:$ to $16: \mathrm{MCs}$ of $\mathrm{BALB} / \mathrm{Mtv}^{+}$.

and $\mathrm{BALB} / \mathrm{Mtv}^{+}$(A 31), and the low level of expression in DD/Tbr MCs (B 13, A 16 and C 62), NIH/ $\mathrm{Mtv}^{+}$MCs (MT 2, N 7 R, N13R and N16R) and BALB/ $\mathrm{Mtv}^{+} \mathrm{MC}$ (E 3).

The level of RNA expression of int -2 gene was also determined in RNAs from MCs and livers by dot blot hybridization analysis (Fig. $3 \mathrm{~A}, 3 \mathrm{~B}$ and Table 1). Its elevated level of expression was observed in 8 of $16 \mathrm{MCs}$ (50\%) from DD/Tbr, 4 of $17 \mathrm{MCs}(24 \%)$ from $\mathrm{NIH} /$ $\mathrm{Mtv}^{+}, 1$ of $9 \mathrm{MCs}(11 \%)$ from BALB/Mtv ${ }^{+}$ mice (Table 1). The int-2 gene was also activated at sigificantly higher frequency in $\mathrm{DD} / \mathrm{Tbr}$ than in $\mathrm{BALB} / \mathrm{Mtv}^{+}$. In some MCs from DD/ Tbr (B 24, B 14 and C 60), NIH/Mtv ${ }^{+}$(M 35) and $\mathrm{BALB} / \mathrm{Mtv}^{+}$(B 1), the levels of expressed int -2 gene were elevated (Fig. 3). Frequency of elevated activation in either int-1 or int-2 genes in MCs from DD/Tbr $(13 / 16 ; 81 \%)$ was significantly higher than those of $\mathrm{NIH} / \mathrm{Mtv}^{+}(8 / 17$; 47) and BALB/ $/ \mathrm{Mtv}^{+}(3 / 9 ; 33 \%)$ (Table 1).

RNA transcripts of int -3 gene was detected in only one MC (B24) out of $16 \mathrm{MCs}$ from DD/ Tbr and none of $17 \mathrm{MCs}$ from $\mathrm{NIH} / \mathrm{Mtv}^{+}$. In all livers from three mouse strains, it was expressed at a very low or an undetectable level.

Status of expression in oncogenes : Expression of oncogenes, $\mathrm{H}$-ras, $\mathrm{K}$-ras, $\mathrm{N}$-ras, c-myc, raf, $f g r, f m s, e r b \mathrm{~B}$, mos, src genes, was also examined in the MCs. Although the expression of $\mathrm{H}$-ras in livers from three strains was undetectable or low, that or the $\mathrm{H}-r a s$ in most MCs from DD/Tbr mice and many MCs from NIH/ $\mathrm{Mtv}^{+}$and $\mathrm{BALB} / \mathrm{Mtv}^{+}$mice was elevated (Table 1). The pattern in $\mathrm{K}$-ras expression was similar to that of $\mathrm{H}$-ras in all strains, but the level of $\mathrm{K}$-ras expression varied largely among individual mice (Table 1). Remarkable increase in myc expression was observed in almost all MCs from three strains (data not shown). Expression of $f g r$ gene was also considerebly elevated in most MCs of all strains when compared with livers. No obvious activation of N-ras, raf, fms, erbB, mos and $s r c$ genes were observed, although RNA transcripts hybridizable with raf, fms and mos probes were detected in a few MCs from BALB/ $\mathrm{Mtv}^{+}$(data not shown).

\section{Discussion}

All mammary tumors examined contained one or more newly acquired MMTV proviruses in addition to endogenous MMTV proviruses [unpublished data]. Increased expression of 
MMTV transcripts might be dut to newly acquired MMTV proviruses. Some of these extra MMTV proviruses were integrated into common integration sites, int -1 , int -2 or int -3 domains. The frequency of integration of MMTV provirus into these sites of MCs varies strikingly among mouse strains [12]. Here we showed that the frequency of MCs with increased level of expression of int-1 or int-2 gene were remarkably different among $\mathrm{DD} / \mathrm{Tbr}$, $\mathrm{NIH} / \mathrm{Mtv}^{+}$and BALB/Mtv ${ }^{+}$mice. This indicates that RNA expression of int genes is attributable at least to genetic characteristics of host animals, because all three strains of mice harbor DD-MMTV of same origin. Thus, the genetic property of host animals is one of important determinants on the extent of int gene expression. MMTV-harboring inbred mouse strains, which have a high mammary tumor incidence such as $\mathrm{C} 3 \mathrm{H} / \mathrm{He}, \mathrm{GR}$, RIII, DD/Tbr and SHN, have a distinct frequency of integration for the int regions of host animals $[7,12]$. However, when the same strain of mice are infected with MMTVs of different origins, whether these viruses have distinct preferences for int sites remains unknown.

Peter et al. (1986) reported a concerted activation of two potential proto-oncogenes in MCs from BR 6 mouse strain [17]. We also observed the concerted activation of int regions in DD-MMTV-induced MCs. In this study, it is consided that the same cell population would express both the int -1 and int -2 genes, because the mammary tumors might consist of a single tumor cell clone [19]. Four out of 9 int-1-positive of DD/Tbr were positive for int -2 expression, and other $5 \mathrm{MCs}$ were int-2 negative. In $\mathrm{NIH} / \mathrm{Mtv}^{+}$mice, 3 out of 7 int-1-positive MCs were also int -2 positive, and the rest 4 were negative. Thus, the expression of int -1 and int2 genes seemed to be regulated independently.

In transgenic mice harboring int -1 gene, the activation of the transgene is associated with hyperplasia of mammary gland. This means that the activation of int-1 gene may be associated with an initiating event in multistep carcinogenesis [24]. Proviral activation of int -2 is considered to be also an early event in the carcinogenesis [16], and even the tumors with activated int -2 gene need further additional events to become hormone independent. On the other hand, malignant activation of $\mathrm{H}-$ ras $^{-1}$ oncogene was found to be involved in the initiation process in mammary carcinogenesis by chemical carcinogen such as $\mathrm{N}$-nitroso- $\mathrm{N}-$ methylurea [23]. In this study, expression of int genes did not show any correlation with that of other oncogenes as far as examined. What roles these oncogenes played in int1-or int-2-positive MC and int-negative MC is not unknown. Interaction of many genes such as oncogenes and suppressor oncogenes would require to be analyze to fully elucidate the mammary carcinogenesis.

This work was made possible by the kindness of Japanese Cancer Research Resouces Bank (JCRB)-Gene in supplying eight oncogenes described in Materials and Methods. We thank M. Ikeda and Y. Ujihara for excellent animal care.

\section{References}

[1] Brown, A. M. C., Papkoff, J., Fung, Y. K. T., Shackleford, G. M., and Varmus, H. E. (1987). Identification of protein products encoded by the proto-oncogene int-1. Mol Cell Biol, 7. 3971-3977.

[2] Dickson, C., Smith, R., Brookes, S, and Peters, G. (1984). Tumorigenesis by mouse mammary tumor virus : Proviral activation of a cellular gene in the common integration region int -2 . Cell, 37, 529-536.

[3] Dickson, C. and Peters, G. (1987). Potential oncogene products related to growth factors. Nature (London), 326, 833.

[4] Finch, P. W., Rubin, J S., Miki, T., Ron, D., and Aaronson, S. A. (1989). Human KGF is FGF-related with properties of a paracrine effector of epithelial cell growth. Science, 245, 752-755.

[5] Gallahan, D. and Callahan, R. (1987). Mammry tumorigenesis in feral mice : identification of a new int locus in mouse mammary tumor virus (Czech II)induced mammary tumors. J. Virol, 61, 66-74.

[6] Imai, S., Morimoto, J., Tsubura, Y., and Hilgers, J. (1980). Mammary tumor virus antigen expression in inbred mouse strains of European origin established in Japan. Jpn. J. Cancer Res (Gann), 71, 419-424.

[7] Iwai, M, Okumoto, M., Nishikawa, R., Iwai, Y., Takamori, Y., and Imai, S. (1990). DNA rearrangement of int region in spontaneous mouse mammary tumors of SHN/S and SLN/S mice. Eur. J. Cancer. Clin Onol, 26, 9-15.

[8] Iwai, Y. (1981). Establishment of DD/Tbr mouse mammary tumor cell lines. J. Nara Med Ass, 32, 168-180.

[9] Moore, R., Casey, G., Brookes, S., Dixon, M., Peters, G., and Dickson, C. (1986). Sequence, topography and protein coding potential of mouse int $2: a$ putative oncogene activated by mouse mammary tumor virus EMBO J., 5, 919-924.

[10] Morris, V. L., Medeiros, E., Ringold, G, M., Bishop, J. M., and Varmus, H. E. (1977). Comparison mammary tumor virus-specific DNA in inbred, wild and Asian mice, and in tumors and normal organs from inbred mice. J. Mol Biol, 114, 73-92.

[11] Nusse, R., van Ooyen, A., Cox, D., Fung, Y. K. T., 
and Varmus, H. E. (1984). Mode of proviral activation of a putative mammary oncogene (int -1$)$ on mouse chromosome 15. Nature, 307, 131-136.

[12] Nusse, R. (1988). The activation of cellular oncogenes by proviral insertion in murine mammary cancer. In Breast Cancer : Cellular and Molecular Biology, pp. 283-306, Lippman, M. E. and Dickson, R. (eds.), Kluwer Academic Publisher, Boston.

[13] Okumoto, M., Nishikawa, R., Iwai, M., Iwai, Y., Takamori, Y., Niwa, O., and Yokoro, K. (1990). Lack of evidence for the involvement of type-C and type- $B$ retroviruses in radiation leukemogenesis of NFS mice. Radiat Res., 121, 267-273.

[14] Papkoff, J., Brown, A. M. C., and Varmus, H. E. (1987). The int-1 proto-oncogene products are glycoproteins that appear to enter the secretory pathway. Mol Cell Biol 7, 3978-3984.

[15] Peters, G., Brookes, S., Smith, R., and Dickson, C. (1983). Tumorigenesis by mouse mammary tumor virus : evidence for a common region for provirus integration in mammary tumors. Cell 33, 369-377.

[16] Peters, G., Lee, A. E., and Dickson, C. (1984). Activation of cellular gene by mouse mammary tumor virus may occur early in tumor development. Nature, 309, 273-275.

[17] Peters, G., Lee, A. E., and Dickson, C. (1986). Concerted activation of two potential proto-oncogenes in carcinomas induced by mouse mammary tumor virus. Nature, 320, 628-631.

[18] Rigby, P. W., Dieckmann, J. M., Rhodes, C., and Berg, P. (1977). Labelling deoxyribonucleic acid to high specific activity in vitro by nick translation with polymerase I. J. Mol Biol, 113, 237-251.

[19] Tanaka, K., Ootsuyama, A., and Tanooka, H. (1984). Clonal origin of spontaneous multiple mammary tumors in mice with cellular mosaicism. Jpn. $J$. Cancer Res, 75, 792-797.

[20] Thomas, P. S. (1980). Hybridization of denatured RNA and small DNA fragments transferred to nitrocellulose. Proc. Natl Acad Sci USA 77, 52015205.

[21] Tsukamoto, A. S., Grosschedl, R., Guzman, R C., Parslow, T., and Varmus, H. E. (1988). Expression of the int -1 gene in transgenic mice is associated with mammary gland hyperplasia and adenocarcinomas in male and female mice. Cell.55, 619-625.

[22] Wilkinson, D. J., Peters, G., Dickson, C., and McMahon, A. P. (1988). Expression of the FGFrelated proto-oncogene int-2 during gastrulation and neurulation in the mouse. EMBO J., 7, 691-695.

[23] Zarbl, H., Sukumar, S., Arthur, A. V., Martin-Zanca, D., and Barbacid, M. (1985). Direct mutagenesis of $\mathrm{Ha}^{-}$ras 1 oncogenes by $\mathrm{N}$-nitroso- $\mathrm{N}$-Methylurea during initiation of mammary carcinogenesis in rats. Nature, 315, 382-385.

\title{
DD/Tbr マウス乳癌ウイルスを保持する 3 系統の マウスの乳癌におけるint遺伝子の発現
}

\author{
森展子・高森康彦**. 矢ヶ崎修*** \\ 大阪府立大学附属研究所応用生体科学部門 \\ *奈良県立医科大学第二病理学教室 \\ **大阪府立大学農学部獣医放射線学教室 \\ ***大阪府立大学農学部獣医薬理学教室
}

奥本正昭·西川量介・岩井峷子.岩井良昭·今井俊介*

$\mathrm{DD} / \mathrm{Tbr}$ マウス, DD/Tbr マウス乳癌ウイルス (DDMMTV) 感染 NIH Swiss マウス $\left(\mathrm{NIH} / \mathrm{Mtv}^{+}\right)$, およ び DD-MMTV 感染 BALB/c マウス (BALB/ $\left.\mathrm{Mtv}^{+}\right)$ の乳癌における MMTV の共通組み込み部位, int 遺伝 子の発現を調べた。DD/Tbr マウスの乳癌 16 例のらち 9 例 (56\%) と8例（50\%）に扎いて，それぞれ int 1 および int-2 遗伝子の発現が增加していた。またこの $\mathrm{DD} / \mathrm{Tbr}$ マウスに発生した 16 例の乳癌のらち 13 例（81 \%) において int -1 と int-2 のいずれかの遺伝子発現の 増加がみられた。一方, $\mathrm{NIH} / \mathrm{Mtv}^{+}$マウスでは 17 例の
乳癌中 7 例 $(41 \%) ， 4$ 例 (24\%) に执いて，それぞれ int -1 および int -2 遺伝子の発現が増加していた。int -1 と int-2のいずれかの遺伝子の発現増加が見られたのは， $\mathrm{DD} / \mathrm{Tbr}$ に比べて明らかに少なく，17 例中 8 例 (47\%) であった。BALB/ $/ \mathrm{Mtv}^{+}$マウスの乳癌ではさらに低く, int-1 と int-2 のいずれかの遺层子の発現増加を示した のは, 9 例中 3 例 (33\%) に過ぎなかった。DD-MMTV で3系統のマゥスにひき抗こした乳癌に批ける int-1 あるいは int -2 遺伝子の発現増加の頻度の違いは, マウ スの系統に固有の遺伝的性質によると考えられる。従っ 
て, 乳癌発生における int -1 と int -2 の寄与の大きさは 宿主細胞側の遺伝的性質によって大きく変わることを示 唆している。また, int -1 および int-2 遺层子の活性化は
$\mathrm{H}$-ras, K-ras, N-ras, myc, raf, fgr, fms, erbB, mos, srcのような癌遗伝子の発現と相関していなか った。 